\title{
Review: Potensi Aktivitas Anti Virus dari Produk Alami Lebah Kelulut
}

\author{
Muhammad Alib Batistuta $^{1}$, Annisa Aulia ${ }^{1}$ dan Paula Mariana Kustiawan ${ }^{1}$ \\ ${ }^{1}$ Fakultas Farmasi, Universitas Muhammadiyah Kalimantan Timur, Jl.Ir.H.Juanda, Samarinda, Kalimantan Timur 75112
}

Reception date of the manuscript: 1 Juli 2021

Acceptance date of the manuscript: 14 Agustus 2021

Publication date: 31 Desember 2021

\begin{abstract}
To date, many deadly diseases are caused by viral infections. Herbal therapy is a preventive effort made by the community to overcome diseases that come from viruses. Antiviral drug resistance is also the reason people consume herbs from natural ingredients. One of the natural products has the potential to come from kelulut bee products consisting of propolis, pollen, and honey. The kelulut bee or Stingless bee is a type of bee that is commonly found in countries with tropical climates such as Indonesia, but there is still little scientific information that examines its potential as an antiviral. This study aims to analyze data on the potential antiviral activity of kelulut bee products through the collection of related articles. The research conducted is a literature review, so the research method is carried out by collecting related articles using search engines such as NCBI, Sciencedirect, and Google Schoolar. Kelulut bee products such as propolis, pollen and honey have potential pharmacological activity as antiviral. This anti-viral activity is due to the presence of compounds such as alkaloids, flavones, apigenin derivatives and other compounds which will be discussed further. Natural products from kelulut bees have potential as an alternative to antiviral therapy. It is also recommended to conduct more in-depth research on the potential of kelulut bee natural products to obtain these therapeutic products.
\end{abstract}

Keywords-Antivirus,Bioactivity, Kelulut bees, Potential.

\begin{abstract}
Abstrak - Sampai saat ini, banyak penyakit mematikan yang disebabkan oleh infeksi virus. Terapi herbal merupakan upaya preventif yang dilakukan masyarakat untuk mengatasi penyakit yang berasal dari virus. Resistensi obat antivirus juga menjadi alasan masyarakat mengkonsumsi herbal dari bahan alam. Salah satu produk alami berpotensi berasal dari produk lebah kelulut yang terdiri dari propolis, polen, dan madu. Lebah kelulut atau stingless bee merupakan jenis lebah yang banyak ditemukan di negara dengan iklim tropis seperti Indonesia, namun masih sedikit informasi ilmiah yang mengkaji potensinya sebagai antivirus.Penelitian ini bertujuan untuk menganalisa data mengenai potensi aktivitas antivirus dari produk hasil lebah kelulut melalui pengumpulan artikel yang berhubungan. Penelitian yang dilakukan adalah literatur review demikian metode penelitian dilakukan dengan mengumpulkan artikel terkait menggunakan mesin pencari seperti NCBI, Sciencedirect, dan Google Schoolar. Produk lebah kelulut seperti propolis, polen dan madu memiliki potensi aktivitas farmakologi sebagai antivirus. Aktivitas antivirus ini disebabkan adanya kandungan senyawa seperti alkaloid, flavon, derivat apigenin dan senyawa lainnya yang akan dibahas lebih lanjut. Produk alami dari lebah kelulut memiliki potensi sebagai alternatif bahan terapi antivirus. Serta disarankan untuk dilakukan penelitian lebih mendalam mengenai potensi produk alami lebah kelulut untuk memperoleh produk terapi tersebut.
\end{abstract}

Kata Kunci-Antivirus, Bioaktivitas, Lebah Kelulut, Potensi.

\section{Pendahuluan}

Lebah kelulut atau Stingless bee adalah spesies lebah penghasil madu yang tergabung dalam Famili Meliponidae. Ciri fisik dari lebah ini adalah tidak memiliki sengat dan berukuran kecil(Francoy et al.,2019). Di alam, lebah kelulut berperan sebagai pollinator untuk banyak tanaman(Sanjaya et al.,2019). Lebah kelulut merupakan lebah madu yang telah diketahui sejak lama sebagai lebah penghasil madu, namun

Penulis koresponden: Paula Mariana Kustiawan, Email: pmk195@umkt.ac.id hingga sekarang lebah jenis ini tidak sepopuler lebah madu lainnya. Madu hasil produksi lebah trigona umumnya lebih sedikit dan lebih sulit untuk diekstrak, tetapi jumlah propolis yang dihasilkan lebih banyak dibandingkan jenis lebah lainnya, serta memiliki rasa madu yang agak asam(Qadariah et al.,2019).

Masyarakat pada jaman dahulu secara empiris menggunakan bahan herbal sebagai penyembuh penyakit. Madu Lebah Kelulut telah digunakkan dan dikonsumsi secara tradisional sejak dulu sebagai nutrien dan juga karena manfaatnya dalam mengobati berbagai penyakit. Menurut penelitian sebelumnya, Madu kelulut biasa digunakan untuk pengobatan luka dengan perannya sebagai nutrisi dalam memperce- 


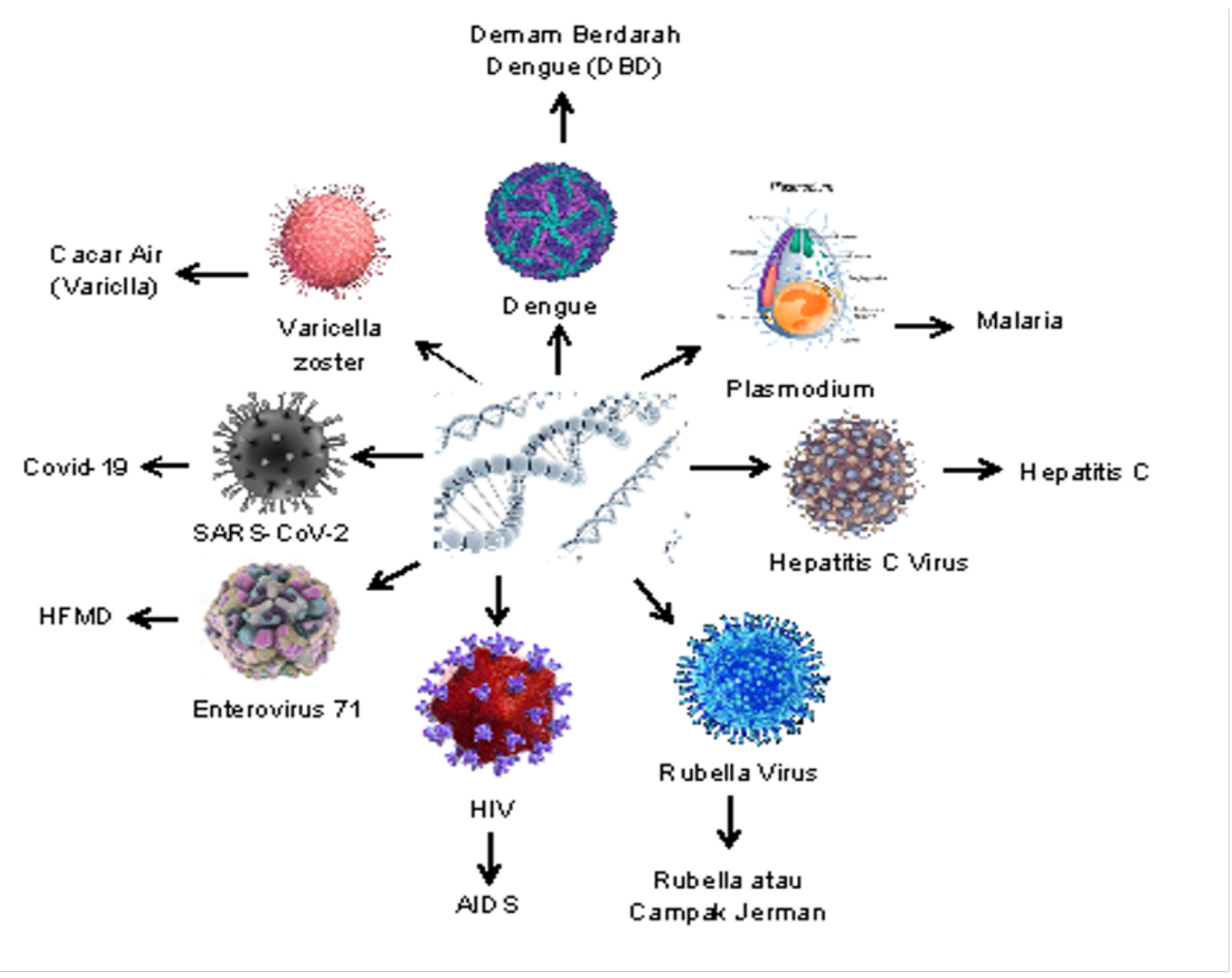

Gambar. 1: Virus dan Penyakit yang disebabkannya

pat penyembuhan luka, debridement luka, antiinflamasi, dan antibakteri(Weliyani et al.,2015). Pada penelitian lain, Secara tradisional, madu lebah kelulut digunakan dalam pengobatan anti penuaan, penyembuhan luka dalam dan batuk dan pilek dengan cepat. Madu lebah kelulut juga dilaporkan memiliki berbagai efek farmakologis seperti anti diabetes, antioksidan dan antibakteri(Yazan et al.,2018). Dan penelitian lainnya menyebutkan, propolis yang dihasilkann oleh lebah kelulut secara empiris diyakini kaya akan khasiat dan relatif aman untuk digunakan sebagai obat herbal(Dinata, 2018). Propolis dihasilkan lebah kelulut untuk mempertahankan diri, akan tetapi banyak masyarakat memanfaatkan propolis sebagai obat herbal yang dapat mengatasi berbagai macam penyakit(Lutpiatina, 2015).

Produk alami lebah kelulut diketahui memiliki manfaatnya diantaranya sebagai antibakteri, antifungi, antikanker, antinflamasi, antiasma(Campos et al.,2015; Lopes et al., 2019; de Farias et al.,2014).

Penyakit infeksi yang diakibatkan oleh virus hingga saat ini masih menjadi permasalahan yang belum terpecahkan sepenuhnya sejak dulu. Virus adalah miikroorganisme dengan yang memiliki satu asam nukleat (DNA atau RNA) yang membutuhkan inang atau makhluk hidup lain untuk dapat melakukan proses replikasi(Beale Block, 2011). Masuknya virus ke inangnya ini menyebabkan terjadinya infeksi. Antivirus adalah senyawa dengan kemampuan untuk mengambat ataupun menghentikan proses replikasi virus. Antivirus umumnya berasal dari bahan sintetis, namun hal ini dapat menyebabkan terjadinya sitotoksik dan juga dapat menyebabkan virus resistensi dan bermutasi sehingga efktivitas dari antivirus menjadi tidak optimal. Sehingga hal ini juga menyebabkan masyarakat lebih memilih pemanfaatan bahan alam sebagai obat tradisional dikarenakan faktor perekonomian yang menurun dan gaya hidup masyarakat yang kembali ke alam(Amanda et al., 2019), juga dikarenakan penggunaan bahan herbal atau alami lebih aman dengan efek samping yang kecil bahkan hampir tidak ada. Penelitian ini bertujuan untuk mengumpulkan informasi dan mengkaji mengenai potensi produk alami lebah kelulut sebagai antivirus.

\section{Metode}

Penelitian ini menggunakan metode literature review. Pengumpulan artikel dilakukan melalui database mesin pencari seperti NCBI, Sciencedirect, dan Google Schoolar. Kata kunci yang digunakan dalam pencarian artikel terkait antara lain "lebah kelulut" atau "stingeless bees" dan "bioaktivitas". Artikel yang dikumpulkan kemudian diperiksa kelayakan dan kesesuaiannya secara manual.

\section{HASIL}

Berdasarkan penelitian yang dilakukan melalui telaah artikel yang membahas mengenai senyawa metabolit dengan aktivitas antivirus dan senyawa yang terkandung didalam produk alami lebah kelulut, maka disajikan dalam bentuk gambar dan tabel dibawah ini.

\section{Pembahasan}

Produk alami lebah kelulut terdiri dari Propolis, Pollen dan Madu. Propolis lebah kelulut secara positif mengandung senyawa metabolit antara lain, Flavonoid, Alkaloid, 
Tabel 1: Kandungan Senyawa Pada Produk Alami Lebah Kelulut

\begin{tabular}{|c|c|c|c|}
\hline Produk Lebah & Jenis Lebah & Golongan Senyawa & Refrensi \\
\hline Propolis & Tetragonula iridipennis & $\begin{array}{l}\text { Alkaloid, Flavonoid, Triterpenoid, } \\
\text { Tannin, Karbohidrat. }\end{array}$ & Khairunnisa et al., 2020 \\
\hline Propolis & Trigona sp. & $\begin{array}{l}\text { Flavonoid, Fenolik, Tannin, } \\
\text { Terpenoid, Saponin, Alkaloid, } \\
\text { Glikosida, Gula Pereduksi. } \\
\text { Allkaloid, Flavonoid, Tanin, }\end{array}$ & Khairunnisa et al., 2020 \\
\hline Propolis & Trigona spp. & $\begin{array}{l}\text { Triterpenoid, Steroid, Saponin, } \\
\text { dan Minyak Atsiri. }\end{array}$ & Kurniawati et al.,2013 \\
\hline Propolis & Lisotrigona cacciae & $\begin{array}{l}\text { Alk(en)ylresorcinols, Asam Anakardat, } \\
\text { Triterpenoid, Flavonoid, Xanton, } \\
\text { Fenolik, Asam Lemak, Dan Ester. }\end{array}$ & Georgieva et al.,2019 \\
\hline Madu & Trigona incisa & Alkaloid, Flavonoid dan Triterpenoid. & Gunawan et al.,2018 \\
\hline Madu & Trigona sp. & $\begin{array}{l}\text { Flavonoid, Alkaloid, Tannin, Saponin. } \\
\text { Asam galat, Asam protokatekuat, }\end{array}$ & Zahra et al.,2021 \\
\hline Madu & Melipona (Michmelia) seminigra marrillae & $\begin{array}{l}\text { Asam-4-Hidroksibenzoat, Katekol, } \\
\text { Isomer Asam Absisat. }\end{array}$ & da Silva et al.,2013 \\
\hline Pollen & Trigona spp. & Alkaloid dan Fenolik. & Syafrizal et al.,2016. \\
\hline
\end{tabular}

Tabel 2: Aktivitas Antivirus Senyawa Metabolit dari Produk Alami Lebah Kelulut

\begin{tabular}{|c|c|c|}
\hline Senyawa Metabolit & Aktivitas sebagai Antivirus & Sumber Referensi \\
\hline & Virus Hepatitis C dapat di inhibisi oleh senyawa Flavonoid dari & \\
\hline \multirow{3}{*}{ Flavonoid } & Ptrigyne nitens. Flavonoid seperti herbacetin juga terbukti memiliki & \\
\hline & kemampuan penghambatan terhadap virus corona dengan menghambat & Indriyanti A \& \\
\hline & $\begin{array}{l}\text { 3C-like protease (3CLpro). Beberapa jenis flavonoid lain juga diketahui } \\
\text { dapat memblok aktivitas enzimatik dari MERS-CoV/3CL pro dan } \\
\text { juga mempunyai efek hambat terhadap SARS-CoV/3CL (pro). }\end{array}$ & Andrianne Y, 2020. \\
\hline Flavonoid (Myricetin) & $\begin{array}{l}\text { Myricetin, salah satu senyawa Flavonoid yang terdapat dalam produk } \\
\text { alami lebah kelulut. Beberapa peneliti menyebutkan bahwa protein helikase } \\
\text { SARS-CoV dapat dihambat oleh myricetin dengan mempengaruhi ATase, }\end{array}$ & Aldoori et al.,2021. \\
\hline Flavonoid (Luteolin) & $\begin{array}{l}\text { Secara in vitro diketahui bahwa jenis flavonoid yaitu Luteolin memiliki } \\
\text { aktivitas antivirus yang kuat terhadap virus influenza. Pada penelitian } \\
\text { lain juga dikatakan bahwa senyawa ini dapat menghambat virus SARS-Cov. }\end{array}$ & $\begin{array}{l}\text { Yan et al., 2019; } \\
\text { Ansari WA, dkk., } 2020 .\end{array}$ \\
\hline Flavonoid (Quercetin) & $\begin{array}{l}\text { Quersetin diketahui memiliki aktivitas antivirus terhadap berbagai macam } \\
\text { jenis virus diantaranya, IAV, Hepatitis C Virus, Enterovirus 71, SARSCoV, dll. } \\
\text { Potensi aktivitas antivirus Quersetin terhadap virus SARS_Cov reatif kuat. } \\
\text { Potensi sebagai inhibitor virus SARS-Cov2 diketahui dimiliki oleh }\end{array}$ & Syamsu RF et al., 2021. \\
\hline Flavonoid (Catechin) & senyawa Catechin, dimana senyawa ini menghambat proses replikasi & Dewi YK \& \\
\hline Flavonoid (Calecnin) & $\begin{array}{l}\text { virus berpotensi dikembangkan menjadi } \\
\text { obat potensial untuk COVID- } 19 \text {. }\end{array}$ & Riyandari BA, 2020. \\
\hline
\end{tabular}

Triterpenoid, Tannin dan Karbohidrat. Penelitian lain menyebutkan, propolis lebah kelulut memiliki beberapa kandungan senyawa yang terdiri dari Asam amino, Terpenoid, dan Polifenol (asam fenolik, ester dan flavonoid)(Amanda et al., 2019). Kandungan senyawa pada propolis lebah kelulu yang ditulliskan oleh beberapa peneliti berbeda antara lain Tocoferol, Quercetin, Vanilic, Asam Caffeic, Asam Ferolik, Asam coumaric, Asam benzoat, Pinobanksin 5-Methyl Ether, Apigenin, Kaempferol, Pinobanksin, Cinnamylideneacetic Acid, Chrysin, Pinocembrin, Galangin, Pinobanksin 3-Acetate, Phenethyl Caffeate, Cinnamyl Caffeate, dan Tectochrysin(Abdullah et al., 2020). Pada polllen atau serbuk sari lebah kelulut terkandung 17 jenis asam amino, termasuk didalamnya asam amino esensial kecuali tryptophan(Da Silva et al., 2014). Selain itu juga ditemukan kandungan mineral berupa Kalium (Ca), Magnesium (Mg), Zinc (Zn), Mangan $(\mathrm{Mn})$, Besi (Fe), dan Tembaga (Cu). Dalam bee pollen juga terkandung senyawa dengan aktivitas antioksidan berupa Flavonoid, Polifenol, dan Karotenid(Taibah, 2019). Berda- sarkan data yang dikumpulkan oleh sebuah studi dari tahun 1964-2006 diketahui bahwa madu dari lebah kelulut sangat kaya akan senyawa metabolit antara lain, Asam Fenolat (Asam Galat, Asam Salisilat, Asam Vanilic, Asam Benzoat, Abscisic Acid, p-Coumaric Acid, Rosmarinic Acid dan beberapa asam fenolat lain), Flavonoid (Hispidulin, Aromadendrin, Myricetin, Cathecol, Apigenin, Quarcetin, Katekin, Isoquercetin), dan senyawa fenolik lain (Vaniln, Umbelliferone, Carnosol, Sinaphaldehyde)(Al Hatamleh, 2017).

Antioksidan adalah senyawa yang memiliki kemampuan untuk menangkap radical bebas. Senyawa antioksidan akan menetralisir radikal bebas dengan cara melakukan pendonoran elektron sehingga tidak menyebabkan gangguan pada metabolisme tubuh(Rahmi, 2017). Berdasarkan penelitian yang dilakukan sebelumnya tentang kemampuan antioksidan pada propolis dari 3 jenis lebah kelulut (G. thoracica; H. itama; T. binghami) diperoleh hasil IC50 yaitu $570.02 \pm$ $6.1 \mathrm{mgL}^{-1} ; 76.5 \pm 1.3 \mathrm{mgL}^{-1} ; 1975 \pm 22.5 \mathrm{mgL}^{-1}$. Dari hasil tersebut diketahui bahwa propoolis dari lebah kelu- 
lut memiliki akivitas antioksidan tinggi. Madu lebah kelulut yang diuji aktivitas antioksidannya denan metode DPPH dan FRAP memperoleh nilai yaitu, $15.07 \pm 1.05 \mathrm{mg} / \mathrm{mL}$ dan $7477.03 \pm 48.80 \mathrm{MFe}(\mathrm{II}) / \mathrm{kg}$. Nilai tersebut menujukkan adanya aktivitas antioksidan pada madu lebah kelulut(Chan et al., 2017). Pollen lebah kelutut yang diuji mennggunakan metode DPPH memiliki nilai IC50 sebesar $273.08 \mu \mathrm{g} / \mathrm{mL}$. Dari penjelasan diatas dapat diketahui bahwa produk alami lebah kelutut (propolis, madu dan pollen) memiliki aktivitas sebagai antioksidan(Lopes et al., 2020).

Imunomodulator merupakan senyawa yang mampu mempengaruhi aktivitas sistem imun tubuh dengan dinamisasi regulasi pada sel sel imun seperti sitokin. Cara kerja Imunomodulator meliputi mengembalikan fungsi imun yang terganggu (imunorestorasi), memperbaiki fungsi sistem imun (imunostimulasi) dan menekan respons imun (imunosupresi). Saat terpapar oleh senyawa atau substrat asing maka akan trjadi dua kemungkinan reeaksi yang dihasilkan oleh sistem imun, yaitu: respon imun non spesifik dan respon imun spesifik. Adanya senyawa-senyawa bioaktif yang dapat meningkatkan aktivitas sistem imun, sangat membantu untuk mengatasi penurunan sistem imun, salah satunya adalah flavonoid. Hasil pengujian secara in vivo maupun in vitro dari metabolit sekunder dari bahan alam seperti flavonoid menunjukkan adanya respon imun atau bersifat imunomodulator(Yusuf, 2019).

Berdasarkan kumpulan data dari penelitian lain ditemukan bahwa senyawa metabolit yang terkandung dalam produk alami lebah kelulut memiliki potensi dan aktivitas sebagai antivirus. Senyawa Flavonoid Quersetin yang terkandung dalam produk alami lebah kelulut memiliki aktivitas dalam penghambatan pertumbuhan beberapa jenis virus seperti IAV, Virus Hepatitis C (HCV), Enterovirus 71, SARS-CoV dan beberapa virus lainnya. Myricetin, senyawa Flavonoid yang terdapat dalam produk alami lebah kelulut mempunyai kemungkinan sebagai antivirus SAR-CoV2(Syamsu et al., 2021). Drivat apigenin yang juga terkandung dalam produk lebah memiliki aktivitas antivirus terhadap Virus Rubella dengan menghambat proses pengikatan virus pada reseptor(Coelho et al., 2018).

\section{KESIMPULAN}

Bedasarkan literatur review yang telah dilakukan diidapatkan kesimpulan bahwa produk alami dari Lebah Kelulut atau Stingless bees mengandung senyawa yang memiliki potensi sebagai antivirus. Diperlukan penelitian lebih lanjut mengenai kemampuan antivirus dari produk Lebah Kelulut.

\section{UCAPAN TERIMA KASIH}

Penulis mengucapkan terima kasih kepada Program Studi S1 Farmasi Universitas Muhammadiyah Kalimantan Timur yang telah memberikan dukungan serta pengarahan sehingga artikel ini dapat terselesaikan.

\section{Daftar Pustaka}

Abdullah NA, Zullkiflee N, Zaini SN. (2020). Phytochemicals, mineral contents, antioxidants, and antimicrobial activities of propolis produced by brunei Stingless bees geniotrigona thoracica, heterotrigona itama, and tetrigona binghami. Studi J Bio Sci., 27(2020): 2902-2911.

Al- Hatamleh MA, Boer JC, Wilson KL, et al. (2020). Antioxidant-based medicinal properties of Stingless bee products: recent progress and future directions. Biomo- lecules, 10(6): 923

Aldoori AN, Ahmed DS, Kadhom M, Yousif E. (2021). Herbal medicine as an alternative method to treat and prevent COVID-19. Baghdad J Biochem Appl Biol Sci., 2(1):1-20.

Amanda EA, Oktiani BW, Panjaitan FU. (2019). Efektivitas antibakteri ekstrak flavonoid propo- lis trigona sp (trigona thorasica) terhadap pertumbuhan bakteri porphyromonas gingivalis. Dentin.

Ansari WA, Ahmad T, Khan MA, Khan ZA Khan MF. (2020). Luteolin: a dietary molecule as potential anti covid - 19 agent. Research Square . https://doi.org/10. 21203/rs.3.rs-35368/v1

Beale JM, Block JH (Ed.). (2011). Wilson and Gisvold's textbook of organic medicinal and pharmaceutical chemistry (12th ed). Philadelphia : Lippincott Williams Wilkins, a Wolters Kluwer business, p. 330-333.

Campos JF, dos Santos UP,da Rocha P dos S, and others. (2015). Antimicrobial, antioxidant, anti-inflammatory, and cytotoxic activities of propolis from the Stingless bee tetragonisca fiebrigi (jataí). Evidence-Based Complementary and Alternative Medicine.

Chan BK, Haron H, Talib RA, Subramaniam P. (2017). Physical properties, antioxidant content and anti-oxidative activities of malaysian stingless kelulut (trigona spp.) honey. J Argicultural Sci., 9(13).

Coelho GR, Figueiredo CA, Negri G, et al. (2018). Antiviral activity of geopropolis extract from scaptotrigona aff. postica against rubella virus. J Food Research, 7(6).

Da Silva GR, da Natividade TB, Camara CA, et al. (2014). Identification of sugar, amino acids and minerals from the pollen of jandaíra Stingless bees (melipona subnitida). Food Nutr. Sci., 5:1015-1021.

da Silva IA, da Silva TM, Camara CA, Queiroz N,Magnani M, et al. (2013). Phenolic profile, antioxidant activity and palynological analysis of Stingless bee honey from amazons, northern brazil. Food Chem, 14(2013):35523558.

de Oliveira RG, Jain S, Freitas LdS, de Arajo ED. (2019). Phenolic compound, nutritional and antioxidant profile of polllen collected by the genus melipona in north eastern brazil. SciELO Braz. J. Food Technol. https://doi.org/10. 1590/1981-6723.07918

de Farias JHC, Reis AS,Arajo MAR, et al. (2014). Effects of Stingless bee propolis on experimental asthma. Evidence-Based Complementary and Alternative Medicine.

Dewi YK, Riyandari BA. (2020). Potensi tanaman lokal sebagai tanaman obat dalam menghambat penyebaran covid-19. Jurnal Pharmascience, 7(2):112-28.

Dinata,Chandra KDN. (2018). Efektivitas antifungi ekstrak propolis lebah kelulut (trigona spp) terhadap pertumbuhan candida albicans. Proceeding Book of Balidence19 Bali Dental Science and Exhibiton. Diakses dari http://repository. maranatha.edu/27629/1/Perception

Francoy TM, Silva RAO, Nunes-Silva P, et al. (2019). Gender identification of five genera of Stingless bees (apidae, meliponini) based on wing morphology. Genet. Mol. Res, 8(1): 207-214.

Georgieva K,Popova M, Dimitrova L, Trusheva B, Thanh LN, and Others. (2019). Phytochemical analysis of 
vietnamese propolis produced by the Stingless bee lisotrigona cacciae. PLos ONE J, 14(4):e0216074. doi:10.1371/journal. pone.0216074.

Gunawan R, Erwin, Syafrizal. (2018). Uji fitokimia dan penentuan aktivitas antioksidan dari madu trigona incisa. Jurnal Atomik, 3(1):18-21.

Khairunnisa B, Rosamah E, Kuspradini H, Kusuma IW, et al. (2020). Uji fitokimia dan antioksidan ekstrak etanol propolis lebah kelulut (tertragonula iridipennis) dari samarinda kalimantan timur. J. Ilm. Manuntung, 6(1):6569.

Khairunnisa K, Mardawati E, Putri SH. (2020). Karakteristik fitokimia dan aktivitas antioksidan ekstrak propolis lebah trigona sp. J. Indust. Pertanian, 02(1):124-129.

Kurniawati D, Rironga H, Wulandari D. (2013). Isolasi dan uji aktivitas antimikroba ekstrak etanol propolis trigona spp. J. Prog. Kim, 3(2):74-80.

Lopes AJO, Vasconcelos CC, Garcia JBS, et al. (2020). Anti-inflammatory and antioxidant activity of pollen extract collected by scaptotrigona affinis postica: in silico, in vitro, and in vivo studies. Antioxidants (Basel), 9(2): 103 .

Lopes AJO, Vasconcelos CC, Pereira FAN, Silva RHM,et al. (2019). Anti inflammatory and activity and antinociceptive activity of pollen extract collected by Stingless bee melipona fasciculata. Int. J. Mol. Sci,20:4512.

Lutpiatina L. (2015). Efektivitas ektrak propolis lebah kelulut (trigona spp) dalam menghambat pertumbuhan salmonella typhi, staphylococcus aureus dan candida albicans. Jurnal Skala Kesehatan, 6(1).

Qadariah L, Andrie M, Taurina W. (2019). Uji sifat fisik sediaan salep kombinasi madu kelulut (heterotrigona itama), ekstrak sirih hijau (piper betle 1.), dan minyak cengkeh (syzygium aromaticum 1.). Jurnal Mahasiswa Farmasi Fakultas Kedokteran Untan, 4(1).

Nugroho, Rudy A., and Syafrizal S. (2015). Uji aktivitas antikoagulan ekstrak propolis Trigona laeviceps terhadap darah mencit (Mus musculus L.). Seminar Sains dan Teknologi FMIPA Universitas Mulawarman.

Rahmi H. (2017). Review: Aktivitas antioksidan dari berbagai sumber buah-buahan di indonesia. Indo. J Agro.,2(1).

Sanjaya V, Astiani D, Sisillia L. (2019). Studi habitat dan sumber pakan lebah kelulut di kawasan cagar alam gunung nyiut di desa pisak kabupaten bengkayang. J Hut. Lestari, 7(2): 786-798.

Syafrizal, Hariani N, Budiman. (2016). Analisis fitokimia, toksisitas dan antioksidan ekstrak serbuk sari (bee pollen) lebah trigona spp. Proceeding of Mulawarman Pharmaceutical Diakses dari: https://prosiding.farmasi.unmul.ac.id/ index.php/mpc/article/view/140.

Syamsu RF, Nuryanti S, Arafah, Jamal MF. (2021). Herbal yang berpotensi sebagai antivirus pada covid-19. Molucca Medica. https://doi.org/10.30598/molmed.2021.v14.i1.76

Taibah S. (2019). Uji aktivitas antioksidan ekstrak etanol bee pollen lebah trigona (trigona itama). Journal of Pharmacy and Science, 3(1):21-8.

Weliyani, Nugroho, RA, Syafrizal S. (2015). Uji aktivitas antikoagulan ekstrak propolis Trigona laeviceps terha- dap darah mencit (Mus musculus L.). Seminar Sains dan Teknologi FMIPA Universitas Mulawarman

Yan H, Ma L, Wang H, Wu S, Huang H, Gu Z, Jiang J Li Y. (2019). Luteolin decreases the yield of influenza a virus in vitro by interfering with the coat protein $\mathrm{i}$ complex expression. Journal of Natural Medicines, 73(3):492494.

Yazan LS, Zainal NA, Ali RM, Zali M, Shyfiq MF, Sze OY, Sim TY, Gopalsamy B, Ling VF,Sapuan S, Esa N. (2018). Antiulcer properties of kelulut honey against ethanol-induced gastric ulcer. Pertanika Journal of Science Technology, 26(1).

Yusuf MI. (2019). Peningkatan imunitas non spesifik (innate immunity) mencit balb/c yang diberi ekstrak etanol daun tumbuhan galing (cayratia trifolia l. domin) enhancement of non specific immunity (innate immunity) mice balb/c given ethanol extract of galing plant (cayratia trifolia 1. domin). Medical Sains: Jurnal Ilmiah Kefarmasian, 3(2):83-92.

Zahra NN, Muliasari H, Andayani Y, Sudarma IM. (2021). Karakterstik fisikokimia ekstrak madu dan propolis trigona sp. asal lombok utara. J. ARGOTEK UMMAT, $8(1)$. 